\title{
ОЦІНКА ЕФЕКТИВНОСТІ ЛІКУВАННЯ АРТЕРІАЛЬНОЇ ГІПЕРТЕНЗІЇ ЗА ДАНИМИ ФАРМАКОЕПІДЕМІОЛОГІЧНОГО ТА ФАРМАКОЕКОНОМІЧНОГО АНАЛІЗУ
}

\author{
Н. В. Віннікова
}

\author{
Тернопільська міська комунальна лікарня № 3
}

Метою даного дослідження було оцінити на основі ретроспективного фармакоепідеміологічного аналізу ефективність лікування артеріальної гіпертензії, дати фармакоекономічну оцінку антигіпертензивних лікарських засобів, розробити шляхи оптимізації антигіпертензивної терапії у хворих в лікарняних закладах охорони здоров’я.

\section{EVALUATING THE EFFECTIVENESS OF TREATMENT OF HYPERTENSION ACCORDING TO FARMACOEPIDEMIOLOGICAL AND PHARMACOECONOMIC ANALYSIS}

\author{
N. V. Vinnikova
}

Ternopil City Municipal Hospital number 3

The aim of this study was to evaluate based on a retrospective analysis of the effectiveness of farmacoepidemiological hypertension, give pharmacoeconomic evaluation of antihypertensive drugs, to develop ways to optimize antihypertensive therapy in patients in hospital health care.

Вступ. Чисельність людей з серцево-судинними хворобами за останні роки значно зросла, що дозволило посісти їм одне з перших місць серед усіх захворювань. Серед них провідною є артеріальна гіпертензія (АГ).

Артеріальна гіпертензія - це захворювання, яке вимагає значних витрат на діагностику та лікування як з боку держави, так і від самого пацієнта. В Україні більше 11 млн людей хворіють на АГ [1], дане захворювання щорічно вперше діагностують у 1 млн осіб [3]. Економічні збитки, зумовлені лікуванням, тимчасовою непрацездатністю, інвалідністю та передчасною смертністю від АГ у США становлять понад 3 млрд доларів, у Швеції - 1,4 млрд доларів, в Іспанії 1,61 млрд доларів [4].

Це вказує на те, що АГ є найдорожчим захворюванням серед хвороб системи кровообігу, що пов'язано зі зростанням вартості діагностики, наявністю великої кількості лікарських засобів та технологій лікування. Група антигіпертензивних препаратів $\epsilon$ однією із достатньо дорогих, у зв'язку із чим постає питання про економічно обґрунтовану терапію.

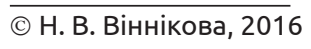

Оцінка ефективності витрат ресурсів при застосуванні ЛЗ здійснюється шляхом фармакоекономічних досліджень. Фармакоекономічні дослідження спрямовані на вивчення економічної доцільності лікарських засобів і схем медикаментозної терапії в нерозривному зв'язку з їх ефективністю і безпечністю $[7,8]$.

Економічна оцінка медикаментозної терапії дає важливу інформацію для оптимізації лікувального процесу. Проведення фармакоепідеміологічних досліджень та фармакоекономічного аналізу відіграє важливу роль в організації раціональної терапії хворих із найбільш значущими за епідеміологічним масштабом, соціальними й економічними наслідками захворювань, до яких належать захворювання органів кровообігу насамперед артеріальна гіпертензія $[2,6]$.

Основна частина. Ефективність лікування АГ і об'єм використаних ресурсів визначали в ретроспективному клініко-економічному дослідженні, яке проведено на базі Тернопільської міської комунальної лікарні № 3. Опрацьовано 254 історії хвороби пацієнтів віком від 40 до 80 років з АГ, які лікувалися у терапевтичному відділенні протягом 2014 року. В карти обстежень вносилась інформація про пацієнта: вік, стать, 
основні й супутні захворювання, медикаментозна терапія, враховувалася добова доза антигіпертензивних засобів та тривалість лікування. У карту включались також дані, необхідні для оцінки ефективності лікування (рівень артеріального тиску - систолічного (САТ) та діастолічного (ДАТ) - перед початком та в кінці лікування). Лікування вважали ефективним, якщо до кінця періоду спостереження (госпіталізації) було досягнуто зниження артеріального тиску до цільового рівня (САТ <140 мм рт. ст., ДАТ $<90$ мм рт. ст.).

Фармакоекономічні дослідження виконані згідно з рекомендаціями з проведення фармакоекономічних досліджень [5]. При проведенні фармакоекономічного аналізу в дослідженні враховано прямі витрати на антигіпертензивну терапію. Для розрахунку витрат на антигіпертензивну терапію користувалися прейскурантом цін аптечних закладів м. Тернополя. Фармакоекономічний аналіз проводили методом «витрати/ефективність», який дозволяє зіставити витрати на ЛЗ із ефективністю лікування.

Показник «витрати/ефективність» розраховували за формулою: $C E R=\frac{C}{E f}$, де CER - показник «витрати/ефективність», що визначає витрати на одного хворого з досягнутим ефектом лікування; С - затрати на антигіпертензивні засоби для одного пацієнта; Еf - ефективність лікування (співвідношення хворих із досягнутим ефектом до загальної кількості пролікованих хворих).

Обстеженим хворим призначали антигіпертензивні ЛЗ першого ряду: діуретики, бета-адреноблокатори, ІАПФ, антагоністи рецепторів АТ, блокатори кальцієвих каналів.

Надалі, хворі були поділені на 4 групи залежно від використаних препаратів (рис. 1). Більшість хворих (92,5 \%) на АГ отримувала комбіновану антигіпертензивну терапію, серед яких переважали такі комбінації:

- діуретик і бета-блокатор (1 група);

- діуретик та ІАПФ або антагоніст рецепторів ангіотензину (2 група);

- бета-блокатор + ІАПФ або антагоніст рецепторів ангіотензину та діуретик (3 група);

- антагоніст кальцію + ІАПФ або антагоніст рецепторів ангіотензину та діуретик (4 група).

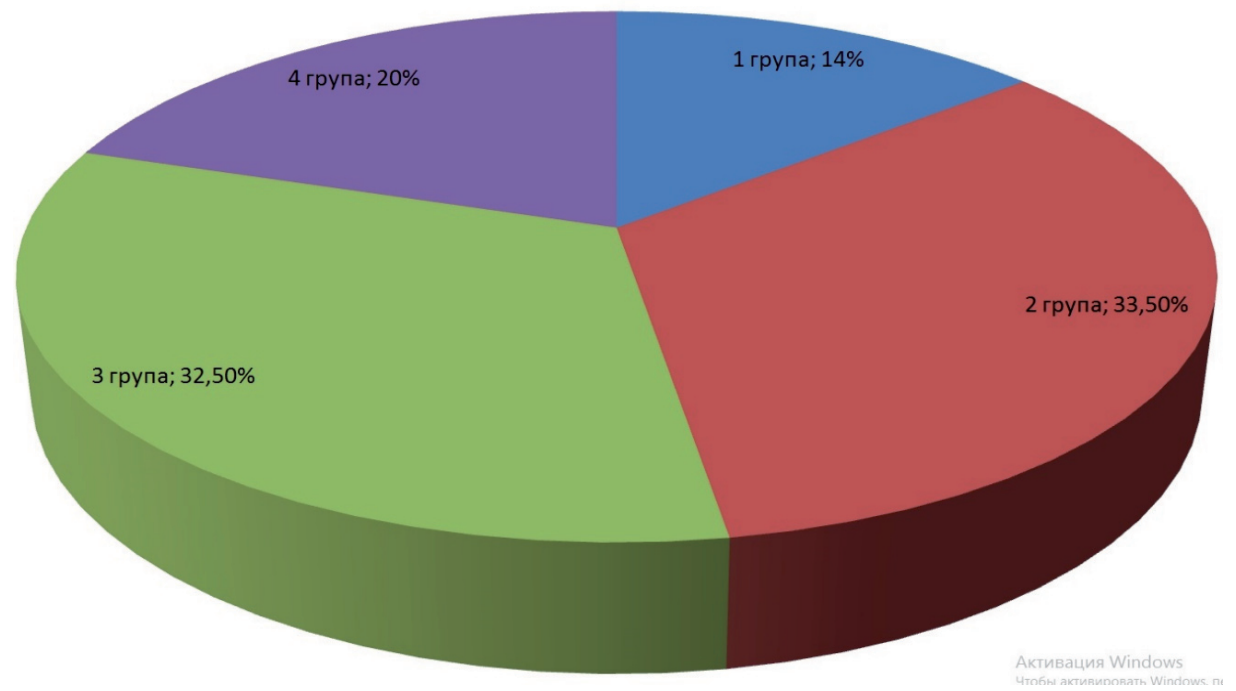

Puc. 1. Використання комбінованої антигіпертензивної терапії окремими групами хворих.

Комбінація бета-адреноблокатора та діуретика належить до рекомендованих комбінацій антигіпертензивних препаратів. Відомо, що бета-блокаторам, поряд з активною гіпотензивною дією, притаманний ряд негативних побічних ефектів, у тому числі підвищення тонусу периферичних судин та затримка натрію, тому їх комбінація з діуретиками, гіпотензивна активність яких зумовлена сечогінною, вазодилатуючою дією, є цілком обумовленою.

Перевагипоєднання ІАПФзтіазидовими діуретиками в малих дозах: посилення антигіпертензивного ефекту ІАПФ; відсутність несприятливих метаболічних змін, можливих при терапії тіазидовими діуретиками у високих дозах; запобігання «вислизуванню» окре- 
мих компонентів нейрогуморальної системи (реніну, ангіотензину-ІІ, альдостерону), характерному для тривалої монотерапії діуретиками або ІАПФ; імовірно, додатковий ефект запобігання судинним ускладненням АГ та зменшення гіпертрофії лівого шлуночка, що потребує перевірки в контрольованих дослідженнях.

Бета-блокатори в комбінації з інгібіторами ангіотензиноперетворювального ферменту (ІАПФ) - золотий стандарт терапії пацієнтів із хронічною серцевою недостатністю.

Бета-блокатори мають ренін-інгібуючий ефект і тому інгібують не лише симпатичну нервову систему, а й РАAС (ренін-ангіотензин-альдостеронова система). Справді, пригнічення ангіотензину-ІІ за допомогою інгібітору АПФ $є$ більш ефективним у пацієнтів, яких також лікують бета-блокатором, i «вислизування» ангіотензину-ІІ від інгібуючої дії інгібітору АПФ послаблюється в пацієнтів, яких лікують бетаблокатором.
Комбінація антагоністів кальцію дигідропіридинового ряду та ІАПФ дає виражений гіпотензивний ефект, спостерігається вираженіший зворотний розвиток гіпертрофії лівого шлуночка і ремоделювання стінки резистивних артерій. При цьому зменшується такий побічний ефект антагоністів кальцію дигідропіридинового ряду як набряк гомілок. Можлива комбінація ІАПФ і антагоністів кальцію недигідропіридинового ряду (верапаміл, дилтіазем), особливо при поєднанні АГ з діабетичною нефропатією.

Результати аналізу отриманих даних засвідчили, що вартість курсу лікування хворого 1 групи становила 417,6 грн, 2 групи - 400,08 грн, 3 групи - 453,6 грн, 4 групи - 452,4 грн, тобто найменша вартість курсу лікування була при призначенні комбінації діуретика та ІАПФ або антагоніст рецепторів ангіотензину (табл. 1).

Аналіз ефективності різних схем лікування хворих на АГ показав, що за період перебування в стаціонарі зниження АТ до цільового рівня зареєстровано

Таблиця 1. Аналіз ефективності різних схем лікування хворих на артеріальну гіпертензію

\begin{tabular}{|c|l|c|c|c|}
\hline Групи & \multicolumn{1}{|c|}{ Схеми лікування } & $\begin{array}{c}\text { Вартість курсу } \\
\text { лікування одного } \\
\text { хворого, грн }\end{array}$ & $\begin{array}{c}\text { Коефіцієнт } \\
\text { вартість/ } \\
\text { ефективність, } \\
\text { лікування, \% } \\
\text { грн на одного }\end{array}$ \\
\hline 1 & Діуретик і бета-блокатор & 417,6 & 94,4 & 442,3 \\
\hline 2 & $\begin{array}{l}\text { Діуретикта ІАПФ або антагоніст рецепторів } \\
\text { ангіотензину }\end{array}$ & 400,08 & 97,7 & 409,5 \\
\hline 3 & $\begin{array}{l}\text { Бета-блокатор + ІАПФ або антагоніст } \\
\text { рецепторів ангіотензину та діуретик }\end{array}$ & 453,6 & 97,6 & 464,7 \\
\hline 4 & $\begin{array}{l}\text { Антагоніст кальцію + ІАПФ або антагоніст } \\
\text { рецепторів ангіотензину та діуретик }\end{array}$ & 452,4 & 96,1 & 470,7 \\
\hline
\end{tabular}

в 94,4 \% пацієнтів 1 групи, 97,7 \% - 2 групи, 97,6 \% 3 групи, 96,1 \% - 4 групи.

Показник «витрати/ефективність» (грн/частота пацієнтів із цільовим АТ у кінці лікування) становив у 1 групі - 442,3, у 2 групі - 409,5, у 3 групі - 464,7, у 4 групі - 470,7.

Отримані дані свідчать про те, що вартість курсу лікування 2 групи (призначення комбінації діуретик та ІАПФ або антагоніст рецепторів ангіотензину) була найменшою, за показником «вартість/ефективність» було виявлено незначну економічну перевагу даної комбінації порівняно з іншими схемами лікування хворих на АГ.
Висновок. Фармакоепідеміологічний та фармакоекономічний аналіз показав, що вартість курсу лікування комбінаціями діуретик та ІАПФ або антагоніст рецепторів ангіотензину була найменшою, за показником «вартість/ефективність», тобто свідчить про економічну перевагу даних комбінацій порівняно з іншими схемами лікування хворих на АГ. Це дозволяє рекомендувати такі комбінації для оптимізації лікувального процесу хворих на артеріальну гіпертензію, що сприятиме покращенню рівня їх здоров'я та якості життя. 


\section{ЛІТЕРАТУРА}

1. Артериальная гипертензия: новые подходы к лечению [Электронный ресурс] // Еженедельник Аптека. 2010. - № 743 (22). - Режим доступа : http://apteka. ua/ article/42547.

2. Зонис Б. Я. Фармакоэкономический анализ антигипертензивной терапии / Б. Я. Зонис, Т. П. Шамрай, О. Ю. Соколов // Проблемы стандартизации в здравоохранении. - 2000. - № 1. - С. 23.

3. Концепція Державної програми профілактики і лікування артеріальної гіпертензії в Україні на 2011-2020 р. Артеріальна гіпертензія. - 2011. - № 2 (6). - С. 12-15.

4. Фармакоекономічний аналіз медикаментозної терапії в практиці сімейного лікаря / Л. П. Купраш,
Л. Ф. Матюха, А. Ю. Петриченко [та ін.] // Сімейна медицина. - 2008. - № 4. - С. 71-73.

5. Экономическая оценка эффективности лекарственной терапии (фармакоэкономический анализ) / под ред.

П. А. Воробьева. - М., 2000. - С. 28-48.

6. Rational prescribing and cost reduction in the treatment of arterial hypertension: a simulation exercise / A. Bonet, V. Gosalbes, M. Fito, J. Navarro // Gac. Sanit. - 2001. - Vol. 15, № 4. - P. 327-335.

7. Maiek M. Health economics of heart failure / M. Maiek // Heart. - 1997. - Vol. 82, № 7. - P. 1-13.

8. O'Brien B. Principles of economic evaluation for health care programs / B. O’Brien // J. Rheumatol. - 1999. - Vol. 22. P. 1399-1402.

Отримано 20.04.16 